\title{
Effect of Seed Priming with Botanicals on Plant Growth and Seed Yield of Lentil (Lens culinaris M.)
}

\author{
Deepak Chand Bhateshwar, Deepti Prabha, Deepak Jangid and Mohammad Salman*
}

Department of Seed Science and Technology, Hemvati Nandan Bahuguna Garhwal University, Srinagar (Garhwal), Uttarakhand (A Central University), India

*Corresponding author

\section{A B S T R A C T}

\begin{tabular}{l} 
Ke y w o r d s \\
$\begin{array}{l}\text { Lentil, Seed } \\
\text { Priming, Botanicals, } \\
\text { Neem leaf extract, } \\
\text { Castor oil, Ginger } \\
\text { extract, Onion } \\
\text { extract, Garlic } \\
\text { extract etc }\end{array}$ \\
$\begin{array}{l}\text { Article Info } \\
\text { Accepted: } \\
\text { 22 June } 2020 \\
\text { Available Online: } \\
\text { 10 July } 2020\end{array}$ \\
\hline
\end{tabular}

\section{Introduction}

Pulses are the edible seeds of plants in the legume family and grown in major area in India. It contributes a significant role in Indian agriculture due to their adaptability in various climatic conditions. In Indian meal, the pulses are used as a source of vegetable protein. Pulses grow in pods and come in a variety of shapes, sizes and colors. The United Nations Food and Agriculture Organization (FAO) recognizes 11 types of

\begin{abstract}
A field experiment was conducted during rabi season, 2018-19 at the Research Farm, Department of Seed Science and Technology, Chauras Campus, H. N. B. Garhwal University, Srinagar (Garhwal), Uttarakhand, India to study the effect of seed priming with botanicals on plant growth and seed yield of lentil (Lens culinaris M.). The experiment was laid out into Randomized Block Design and replicated three times. The field experiment consisted of six treatments viz., seed priming with neem leaf extract $(50 \%)$, castor oil (20\%), ginger extract (50\%), onion extract (50\%) and garlic extract $(50 \%)$ and control. The seed priming with $50 \%$ extract of garlic inhibits germination due to the presence of Allicin. The maximum germination percentage (90.80\%), number of branches per plant (5.20), seeds per pod (1.87), 1000 seeds weight $(20.24 \mathrm{~g})$, yield per plant $(3.51 \mathrm{~g})$ and yield per ha $(9.94 \mathrm{~g})$ were observed when seeds were primed with neem leaf extracts $(50 \%)$. Whereas, maximum plant height at 60 DAS $(12.80 \mathrm{~cm})$ and number of pods per plant $(174.73)$ were observed when seeds were primed with onion extract $(50 \%)$.
\end{abstract}

pulses: dry beans, dry broad beans, dry peas, Bambara beans, pigeon peas, chickpeas, cow peas, lentils, vetches, lupins and pulses nes. Pulses are healthy, nutritious and easy to cook with. Growing pulses also promotes sustainable agriculture, as pulse crops help decrease greenhouse gases, increase soil health, and use less water than other crops.

Importantly, seed priming has shown its effectiveness in improving seed germination, seedling growth and crop stand against the 
negative impacts brought about by stress in the field. Seed priming is a commercially used technique for improving seed germination and vigour. It involves imbibitions of seeds in water under controlled conditions to initiate early events of germination, followed by drying the seed back to its initial moisture content (Varier et al., 2010).Treatment with water, salt solution, certain hormones, organic and inorganic chemicals, and pesticides, etc. (Vasileva and Ilieva, 2007) are primarily practiced in seed priming. Also, pre-soaking, hardening, hormonal priming, hydropriming, halopriming, Osmoconditioning, and ascorbate priming are some common priming techniques to improve speed and synchrony of seed germination. Botanical priming is new endeavor and many botanical extracts have been studied for their effect on seed and seedling parameters.

In recent years, the use of local botanicals has gained much importance, mainly among researchers, because of its high benefits in plant growth, yield and seed quality attributes. The neem tree, Azadirachtinindica, a source of several insecticidal alkaloids is a subtropical tree native to the arid areas of Asia and Africa (Saha et al., 2006). Azadirachtin is the main pesticidal component of neem. Neem products are naturally available materials, cheaper, and also safe for beneficial organisms. Seed treatment with neem leaf extract and their use in agriculture is increasing because of beneficial effects on plants. Some other botanicals like garlic extract, onion extracts, castor oil etc. can also be used for seed treatment and various effect of them can be seen on growth and yield of a plant. Botanical seed treatment is extracted from naturally occurring sources based on botanical ingredients. It has synergistic effect on early and uniform seed germination and enhances tolerance to pest and disease during early crop stage. Botanical extracts been reported to possess antifungal activities against seed borne fungies (Suratuzzaman et al., 1994; Ashrafuzzaman and Hossain, 1992; Hossain and Schlosser 1993). Botanicals have been found to be effective for reduction of population of Fusarium associate with seed (Bowers and Locke, 2000). Available literature indicate that plant extracts and plant essential oils possess effective antimicrobial principles against food and grain storage fungi (Mishra and Dubey, 1994).

\section{Materials and Methods}

\section{Climate}

In the experimental site except during the rainy season, rests of the months are usually dry, with exception of occasional showers during winter or early spring. Srinagar Garhwal region comes under sub-tropical climate, with both extremes in the temperature i.e., winter and summer. The monthly meteorological data on various weather parameters were recorded at meteorological observatory of Research Farm, Department of Seed Science and Technology, Chauras Campus, H. N. B. Garhwal University, Srinagar, Garhwal, Uttarakhand (India), during the whole experimental period in 2018-19.

The data for the climatic features of the experimental site have been recorded during the period of experimental trail i.e, November-March and is presented in the following figure. 1 .

\section{Meteorological data}

The Research farm falls under humid and subtropical climatic condition which exhibits dry summer and rigorous winter with occasional dense fog from mid-November to midFebruary. In winter, there is less rainfall comparison to summer season. The 
temperature reaches $45^{\circ} \mathrm{C}$ on some days from May-June and $2{ }^{\circ} \mathrm{C}$ in December-January. The maximum temperature range between $13^{\circ} \mathrm{C}$ $26^{\circ} \mathrm{C}$ and minimum between $5{ }^{\circ} \mathrm{C}-20^{\circ} \mathrm{C}$. The maximum precipitation during experiment is $16.3 \mathrm{~mm}$ mostly received during December and minimum during November.

The data of temperature, relative humidity and rainfall during the experiment was obtained from the meteorological observatory of Horticulture Research Centre, Department of Horticulture, Chauras Campus, Srinagar Uttarakhand has been presented in appendix I and depicted in fig. 1.

\section{Soil condition}

In order to find out the soil texture, response and fertility status, a composite soil sample representing the distinct areas of the experimental site was drawn from the experimental plot from $0-20 \mathrm{~cm}$ depth before transplanting the crop. Prepared and processed composite soil sample was analyzed at departmental laboratory and the results thus obtained have been presented in the table

\section{Materials}

During the course of experiment, Lentil CV. PL-8was used. This variety is developed by $\mathrm{G}$ B Pant University of Agriculture and Technology, Pantnagar, Uttarakhand. The fruits of this variety are green and long tender. It is long duration crop. This variety is high fruit weight and good bearing.

\section{Land preparation}

Through ploughing, the ground was carried to a good tilth, and two crosses were harrowing. The beds were ready and channels for adequate irrigation were supplied.

\section{Fertilizer application}

15 t/ha FYM were applied in the field and then cross ploughing was done with the help of tractor so that FYM could be mixed thoroughly.

\section{Preparation of botanical extracts}

\section{Preparation of stock solution}

The stock solution of botanical extracts was prepared by grinding the $25 \mathrm{~g}$ of botanical with adding $25 \mathrm{ml}$ water in it. By this, 1:1 solution of all the botanicals was prepared. In case of neem, leaves were used, while rhizomes in ginger, bulbs in onion and cloves in garlic were used to prepare stock solution.

\section{Method of priming}

The $50 \%$ solution of botanicals was prepared for priming of seeds. The $20 \%$ solution of castor oil was prepared by adding $10 \mathrm{ml}$ oil into $40 \mathrm{ml}$ of distilled water.

The seeds were kept overnight into solution for soaking. On the next day, the seeds were dried into shade and sown into respective plots.

\section{Sowing}

The seeds were sown done on 15 November, 2018 by manually with 2 seeds at a location, at a depth of 3-4 cm in the rows which were prepared before sowing.

\section{Irrigation}

The crop was raised in winter season, so much irrigation was not needed. The light irrigation was given after sowing followed by after ten days of interval. Thereafter, irrigations were given as per the requirement. 


\section{Thinning}

The thinning was done at 35 days after sowing of seeds to obtain optimum plant population in each experimental plot.

\section{Intercultural operations}

Hoeing and weeding operations were done whenever required. Necessary plant protection measures were being taken up to protect the crop from pest and diseases.

\section{Harvesting}

Harvesting was done after the seeds attained physical maturity. The harvesting of the crops was done on 9 March, 2019.

\section{Observations recorded}

Five plants were randomly selected from each plot. The following observations were recorded on the different growth and yield parameters. The characters studied under the present experiment are listed below.

\section{Growth parameters}

\section{Germination percentage (\%)}

Number of germinated seeds were recorded every $48 \mathrm{~h}$ after initiation of germination until 10 days. Germination percentage was calculated (Association of Official Seed Analysis 1983) as follows:

Germination percentage $=($ No. of seed germinated/ Total No. of seed sown) $\times 100$

\section{Plant height at 60 and 90 DAS}

Height of the selected plants was measured from the base of the plant (soil surface) up to the growing tip of the main stem with meter scale and expressed in centimetres. It was recorded at 60 and 90 DAS and at maturity under irrigated and rainfed conditions.

\section{Number of branches}

Five plants from each replication were selected and number of branches was counted and the mean was calculated.

\section{Plant Fresh weight}

Five plants from each replication were uprooted at 60 DAS and their weight was measured with the help of balance machine and expressed in gram.

\section{Total Dry matter}

Five plants from each replication were uprooted at 60 DAS and oven dried at $65^{\circ} \mathrm{C}$ till constant weight was obtained. Plant dry weight was expressed as $\mathrm{g}$ plant $^{-1}$.

\section{Days to 50\% flowering}

The time taken to produce flower by $50 \%$ of plants in each treatment of each replication was recorded and days counted by date of sowing.

\section{Stem dry weight}

Five plants from each plot were uprooted at the time of $50 \%$ flowering and their main stem was separated. The stem than oven dried at $65{ }^{\circ} \mathrm{C}$ for $24 \mathrm{~h}$ and their weight was measured at balance machine and expressed in gram.

\section{Leaf dry weight}

Five plants from each plot were uprooted at the time of 50\% flowering and their leaves were separated. The leaves than oven dried at $65{ }^{\circ} \mathrm{C}$ for $24 \mathrm{~h}$ and their weight was measured at balance machine and expressed in gram. 


\section{Yield Parameters}

\section{Number of pods per plant}

Pods of 5 plants were selected randomly at maturity from each treatment and counted and average number of pods plant ${ }^{-1}$ was calculated.

\section{Number of seeds per pod}

After threshing the bunch of five plants, number of seeds were counted and divided with total number of pods recorded from these five plants.

\section{Yield per plant $(g)$}

After threshing, the total yield of five tagged plants per plot was weighed and the resultant was divided by the total tagged plants and the seed yield per plant was obtained.

\section{Yield per plot (g)}

Seed yield of each net plot was weighed and recorded after threshing and winnowing.

\section{Yield per hactere (kg)}

Straw yield was calculated in $\mathrm{kg}$ by subtracting the grains yield from the biological yield.

\section{Test weight (100) seeds (g)}

One hundred seeds were randomly taken from the harvest (8\% seed moisture) and weighed on a precision balance to record their mass.

\section{Statistical analysis}

The statistical analysis for all the characters studied was done by method recommended by Panse and Sukhatme, (1961) for Randomized Block Design and for the statistical analysis of data. The CD (Critical Difference) at 5\% level of significance for each character was worked out.

\section{Results and Discussion}

In further studies garlic was not use after germination because 50 Percent of garlic reduces germination to $0 \%$.

In this study results of the experiment entitled Effect of Seed Priming with Botanical Extracts on Plant Growth and Yield of Lentil (Lens culinaris M.) obtained during the course of investigation are summarized with the help of suitable table and graphs. The botanical seed treatments were found significant for different morphological fetures of lentil.

\section{Growth parameters}

\section{Germination percentage}

It is evident from Table 4.1 that the seed priming with neem leaf extracts resulted as maximum germination percentage $(90.80 \%)$ followed by $\mathrm{T}_{5}(89.23 \%)$ and $\mathrm{T}_{4}(88.44 \%)$ when compared to control $(86.01 \%)$. No seeds were germinated when the seeds were primed with 50\% garlic extracts (Fig.2).

\section{Plant height}

The data pertaining to the plant height given in the Table 4.2indicated thatthere was significant difference in plant height at 90 DAS (Fig.3). Maximum plant height (34.27 $\mathrm{cm}$ ) was observed in treatment $\mathrm{T}_{4}$, followed by $\mathrm{T}_{5}(33.80 \mathrm{~cm})$ and $\mathrm{T}_{3}(31.93 \mathrm{~cm})$. Whereas, least plant height (28.80) was observed in control. There was no significant difference in plant height at 60 days after sowing.

\section{Number of branches per plant}

It is revealed from observed data presented in Table 4.2 that there was significant difference 
between treatments in relation to number of branches per plant (Fig.4). Higher number of branches (5.20) were recorded in $\mathrm{T}_{2}$ followed by $\mathrm{T}_{4}$ (4.53) and $\mathrm{T}_{3}$ (4.33). While the lowest number of branches (3.60) were observed in which was at par with $\mathrm{T}_{5}(4.40)$.

\section{Plant freshweight $(\mathrm{g})$}

Various seed priming treatments shown significant difference in fresh weight of plant at 60 DAS (Fig.5). Higher plant weight was observed in $\mathrm{T}_{3}(25.77 \mathrm{~g})$ when compared to control (19.12 g). Treatments $\mathrm{T}_{5}, \mathrm{~T}_{2}$ and $\mathrm{T}_{4}$ were recorded plant fresh weight $24.13 \mathrm{~g}$, $20.45 \mathrm{~g}$ and $20.20 \mathrm{~g}$, respectively (Table 4.3).

\section{Total dry matter (g)}

Seed priming with various botanical extracts revealed significant difference in total dry matter of plant at 60 DAS (Fig. 4.5). Maximum total dry matter $(6.50 \mathrm{~g})$ was observed in $\mathrm{T}_{3}$, while the least total dry matter $(4.75 \mathrm{~g})$ was recorded in control which was at par with $\mathrm{T}_{5}, \mathrm{~T}_{2}$ and $\mathrm{T}_{4}$, respectively in ascending order (Table 4.3).

\section{Days to $50 \%$ flowering}

It is evident from the Table 4.4 that there was significant difference between the treatments in relation to days to $50 \%$ flowering (Fig. 5). Maximum days to produce $50 \%$ of flowers (63.67 days) were taken by control. Seed priming with onion extracts was resulted as minimum days (56.33 days) for producing $50 \%$ of flowers.

\section{Stem dry weight at $50 \%$ flowering}

The data in Table 4.4 indicating that maximum stem dry weight $(641.67 \mathrm{mg})$ at the time of $50 \%$ flowering was observed in $\mathrm{T}_{4}$ followed by $\mathrm{T}_{5}(511 \mathrm{mg}), \mathrm{T}_{2}(500.33 \mathrm{mg})$ and $\mathrm{T}_{3}$ (492.67 mg). Minimum dry weight (438.67 $\mathrm{mg}$ ) was observed in control.

\section{Leaf dry weight at $50 \%$ flowering}

The data in relation to leaf dry weight at the time $50 \%$ flowering was revealed significant difference between treatments (Fig.7). The maximum leaf dry weight was observed in $\mathrm{T}_{5}$ $(3.57 \mathrm{~g})$ followed by $\mathrm{T}_{4}(3.54 \mathrm{~g}), \mathrm{T}_{2}(3.32 \mathrm{~g})$ and $\mathrm{T}_{3}(2.50 \mathrm{~g})$. Whereas, the minimum leaf dry weight $(2.46 \mathrm{~g})$ was observed in control (Table 4.4).

\section{Yield parameters}

\section{Pods per plants}

The data on number of pods per plant, presented in Table 4.5 indicated significant differences between various treatments (Fig. 8).Among the treatments, $\mathrm{T}_{5}$ recorded significantly higher number of pods per plant (174.73), followed by $\mathrm{T}_{2}$ (157.47), $\mathrm{T}_{4}(149.40)$ and $\mathrm{T}_{3}$ (135.80). Whereas, minimum number of pods per plants was found in $\mathrm{T}_{1}(118.40)$.

\section{Seeds per pods}

It is evident from Table 4.5 that result indicated significant differences between various treatments (Fig.9). Among the treatments, $\mathrm{T}_{2}$ and $\mathrm{T}_{4}$ recorded similar and higher number of seeds per pods (1.87), which were followed by $\mathrm{T}_{5}(1.86), \mathrm{T}_{3}(1.81)$. Whereas, minimum number of seeds per pods (1.76) was found in $T_{1}$.

\section{Yield per plant (g)}

\section{Plant (g)}

The data on yield per plant, presented in Table 4.6 indicated significant differences between various treatments (Fig.10).Among the treatments, $\mathrm{T}_{5}$ recorded significantly higher yield per plant $(3.90 \mathrm{~g})$, followed by $\mathrm{T}_{2}$ $(3.51 \mathrm{~g}), \mathrm{T}_{3}(3.46 \mathrm{~g})$ and $\mathrm{T}_{4}(135.80 \mathrm{~g})$. Whereas, minimum yields per plant (3.27 g) was found in $T_{1}$. 


\section{Yield per plot (g)}

The data with respect to yield per plot, given in Table 4.6has shown significant differences between various treatments (Fig.11). Among the treatments, $\mathrm{T}_{2}$ recorded significantly higher yield per plot $(167 \mathrm{~g})$, followed by $\mathrm{T}_{5}$ $(160 \mathrm{~g}), \mathrm{T}_{3}(148 \mathrm{~g})$ and $\mathrm{T}_{4}(144 \mathrm{~g})$. Whereas, minimum yield per plot $(139 \mathrm{~g})$ was found in $\mathrm{T}_{1}$.

\section{Yield per hectare (q)}

In relation to yield per hectare, $T_{2}$ recorded significantly higher yield per hectare $(9.94 \mathrm{q})$, followed by $\mathrm{T}_{5}(9.56 \mathrm{q}), \mathrm{T}_{3}(8.83 \mathrm{q})$ and $\mathrm{T}_{2}$ $(8.57$ q). Whereas, minimum yield per hectarewas found in $\mathrm{T}_{1}(8.29 \mathrm{q})$.

Table.1 Soil analysis of experimental plot

\begin{tabular}{|l|l|l|}
\hline S.No. & Properties & Value \\
\hline $\mathbf{1}$ & Texture & Sandy clay \\
\hline $\mathbf{2}$ & Soil Ph & 6.3 \\
\hline $\mathbf{3}$ & Organic carbon $(\%)$ & 0.85 \\
\hline $\mathbf{4}$ & Available nitrogen $(\mathrm{kg} / \mathrm{ha})$ & 94.3 \\
\hline $\mathbf{5}$ & Available phosphorus $(\mathrm{kg} / \mathrm{ha})$ & 3.55 \\
\hline $\mathbf{6}$ & Available potassium $(\mathrm{kg} / \mathrm{ha})$ & 131 \\
\hline
\end{tabular}

Experimental details

\begin{tabular}{|l|l|l|}
\hline $\mathbf{1}$ & Experimental design & Randomized Block Design \\
\hline $\mathbf{2}$ & Number of replications & 3 \\
\hline $\mathbf{3}$ & Number of treatments & 6 \\
\hline $\mathbf{4}$ & Total number of plots & 18 \\
\hline $\mathbf{5}$ & Spacing & $30 \times 10 \mathrm{~cm}$ \\
\hline $\mathbf{6}$ & Plot size & $1.2 \times 1.4$ metres \\
\hline $\mathbf{7}$ & Variety used & PL-8 \\
\hline $\mathbf{8}$ & Date of sowing & $15-$ November-2018 \\
\hline $\mathbf{9}$ & Date of Harvesting & 9 March, 2019 \\
\hline & & \\
\hline & & \\
\hline
\end{tabular}

Details of treatments

\begin{tabular}{|l|l|l|}
\hline Sr. No. & Treatment No. & Treatments \\
\hline $\mathbf{1 .}$ & T1 & Control \\
\hline $\mathbf{2 .}$ & T2 & Neem leaf extract \\
\hline $\mathbf{3 .}$ & T3 & Castor oil \\
\hline $\mathbf{4 .}$ & T4 & Ginger extract \\
\hline $\mathbf{5 .}$ & T5 & Onion extract \\
\hline $\mathbf{6 .}$ & T6 & Garlic extract \\
\hline
\end{tabular}


Table.4.1 Effect of seed priming with botanicals on germination percentage of lentil

\begin{tabular}{|l|l|c|}
\hline \multicolumn{2}{|l|}{ Treatments } & Germination percentage (\%) \\
\hline $\mathbf{T}_{\mathbf{1}}$ & Control & 86.01 \\
\hline $\mathbf{T}_{\mathbf{2}}$ & Neem leaf extract & 90.80 \\
\hline $\mathbf{T}_{\mathbf{3}}$ & Castor oil & 81.25 \\
\hline $\mathbf{T}_{\mathbf{4}}$ & Ginger extract & 88.44 \\
\hline $\mathbf{T}_{\mathbf{5}}$ & Onion extract & 89.23 \\
\hline $\mathbf{T}_{\mathbf{6}}$ & Garlic extract & 0.00 \\
\hline S.EM. & & $\mathbf{1 . 0 4}$ \\
\hline CD at 5\% & & $\mathbf{3 . 2 8}$ \\
\hline
\end{tabular}

Table.4.2 Effect of seed priming with botanical extracts on Plant Height at 60 DAS and 90 DAS and number of branches

\begin{tabular}{|l|l|c|c|c|}
\hline \multicolumn{2}{|l|}{ Treatments } & Plant height at 60 DAS & Plant height at 90 DAS & Number of branches per plant \\
\hline $\mathbf{T}_{\mathbf{1}}$ & Control & 12.67 & 28.80 & 3.60 \\
\hline $\mathbf{T}_{\mathbf{2}}$ & Neem leaf extract & 13.00 & 30.07 & 5.20 \\
\hline $\mathbf{T}_{\mathbf{3}}$ & Castor oil & 13.20 & 31.93 & 4.33 \\
\hline $\mathbf{T}_{\mathbf{4}}$ & Ginger & 14.73 & 34.27 & 4.53 \\
\hline $\mathbf{T}_{\mathbf{5}}$ & Onion & 12.80 & 33.80 & 4.40 \\
\hline S.EM. & & $\mathbf{0 . 9 0}$ & $\mathbf{0 . 7 1}$ & $\mathbf{0 . 1 3}$ \\
\hline CD at 5\% & $\mathbf{N S}$ & $\mathbf{2 . 3 3}$ & $\mathbf{0 . 4 4}$ \\
\hline
\end{tabular}

Table.4.3 Effect of seed priming with botanicals on Plant fresh weight and dry weight at 60 DAS

\begin{tabular}{|l|c|c|}
\hline Treatments & Plant fresh weight at 60 DAS & Total dry matter at 60 DAS \\
\hline Control & 19.12 & 4.75 \\
\hline Neem leaf extract & 20.45 & 5.40 \\
\hline Castor oil & 25.77 & 6.50 \\
\hline Ginger & 20.20 & 4.90 \\
\hline Onion & 24.13 & 5.87 \\
\hline S.EM. & 0.49 & 0.35 \\
\hline CD at 5\% & 1.60 & 1.16 \\
\hline
\end{tabular}

Table 4.4 Effect of seed priming with botanicals on Days to $50 \%$ flowering, Stem dry weight at $50 \%$ flowering and Leaf dry weight at $50 \%$ flowering

\begin{tabular}{|l|l|c|c|c|}
\hline \multicolumn{2}{|l|}{ Treatments } & $\begin{array}{c}\text { Days to 50\% } \\
\text { flowering }\end{array}$ & $\begin{array}{c}\text { Stem dry weight at 50\% } \\
\text { flowering (mg) }\end{array}$ & $\begin{array}{c}\text { Leaf dry weight at 50\% } \\
\text { flowering (g) }\end{array}$ \\
\hline $\mathbf{T}_{\mathbf{1}}$ & Control & 63.67 & 438.67 & 2.46 \\
\hline $\mathbf{T}_{\mathbf{2}}$ & Neem leaf extract & 60.67 & 500.33 & 3.32 \\
\hline $\mathbf{T}_{\mathbf{3}}$ & Castor oil & 58.33 & 492.67 & 2.50 \\
\hline $\mathbf{T}_{\mathbf{4}}$ & Ginger & 59.67 & 641.67 & 3.54 \\
\hline $\mathbf{T}_{\mathbf{5}}$ & Onion & 56.33 & 511.00 & 3.57 \\
\hline S.EM. & $\mathbf{0 . 9 4}$ & $\mathbf{6 . 8 8}$ & $\mathbf{0 . 1 0}$ \\
\hline CD at 5\% & $\mathbf{3 . 0 7}$ & $\mathbf{2 2 . 4 3}$ & $\mathbf{0 . 3 2}$ \\
\hline
\end{tabular}


Table.4.5 Effect of seed priming with botanicals on Pods per plant and Seeds per pod

\begin{tabular}{|l|l|c|c|}
\hline \multicolumn{2}{|l|}{ Treatments } & Pods per plant & Seeds per pod \\
\hline $\mathbf{T}_{\mathbf{1}}$ & Control & 118.40 & 1.76 \\
\hline $\mathbf{T}_{\mathbf{2}}$ & Neem leaf extract & 157.47 & 1.87 \\
\hline $\mathbf{T}_{\mathbf{3}}$ & Castor oil & 135.80 & 1.81 \\
\hline $\mathbf{T}_{\mathbf{4}}$ & Ginger & 149.40 & 1.87 \\
\hline $\mathbf{T}_{\mathbf{5}}$ & Onion & 174.73 & 1.86 \\
\hline S.EM. & $\mathbf{4 . 3 3}$ & $\mathbf{0 . 0 2}$ \\
\hline CD at & $\mathbf{5 \%}$ & $\mathbf{3 . 8 4}$ & $\mathbf{0 . 0 8}$ \\
\hline
\end{tabular}

Table.4.6 Effect of seed priming with botanicals on yield per plant,yield per plot and yield per hector

\begin{tabular}{|l|l|c|c|c|}
\hline \multicolumn{2}{|l|}{ Treatments } & yield per plant $\mathbf{( g )}$ & Y yield per plot(g) & yield per hector(qt) \\
\hline $\mathbf{T}_{\mathbf{1}}$ & Control & 3.27 & 139.33 & 8.29 \\
\hline $\mathbf{T}_{\mathbf{2}}$ & Neem leaf extract & 3.51 & 167.00 & 9.94 \\
\hline $\mathbf{T}_{\mathbf{3}}$ & Castor oil & 3.46 & 148.33 & 8.83 \\
\hline $\mathbf{T}_{\mathbf{4}}$ & Ginger & 3.42 & 144.00 & 8.57 \\
\hline $\mathbf{T}_{\mathbf{5}}$ & Onion & 3.90 & 160.67 & 9.56 \\
\hline S.EM. & $\mathbf{0 . 1 2}$ & $\mathbf{5 . 8 1}$ & $\mathbf{0 . 3 5}$ \\
\hline CD at 5\% & $\mathbf{0 . 3 8}$ & $\mathbf{1 8 . 9 5}$ & $\mathbf{1 . 1 3}$ \\
\hline
\end{tabular}

Table.4.7 Effect of seed priming with botanicals on 1000 seeds weight $(\mathrm{g})$

\begin{tabular}{|c|c|c|}
\hline & Treatments & 1000 seeds weight $(\mathbf{g})$ \\
\hline $\mathbf{T}_{\mathbf{1}}$ & Control & 17.83 \\
\hline $\mathbf{T}_{\mathbf{2}}$ & Neem leaf extract & 20.24 \\
\hline $\mathbf{T}_{\mathbf{3}}$ & Castor oil & 19.07 \\
\hline $\mathbf{T}_{\mathbf{4}}$ & Ginger & 18.59 \\
\hline $\mathbf{T}_{\mathbf{5}}$ & Onion & 18.73 \\
\hline & S.EM. & $\mathbf{0 . 4 5}$ \\
\hline & CD at 5\% & $\mathbf{1 . 4 6}$ \\
\hline
\end{tabular}

Fig.1

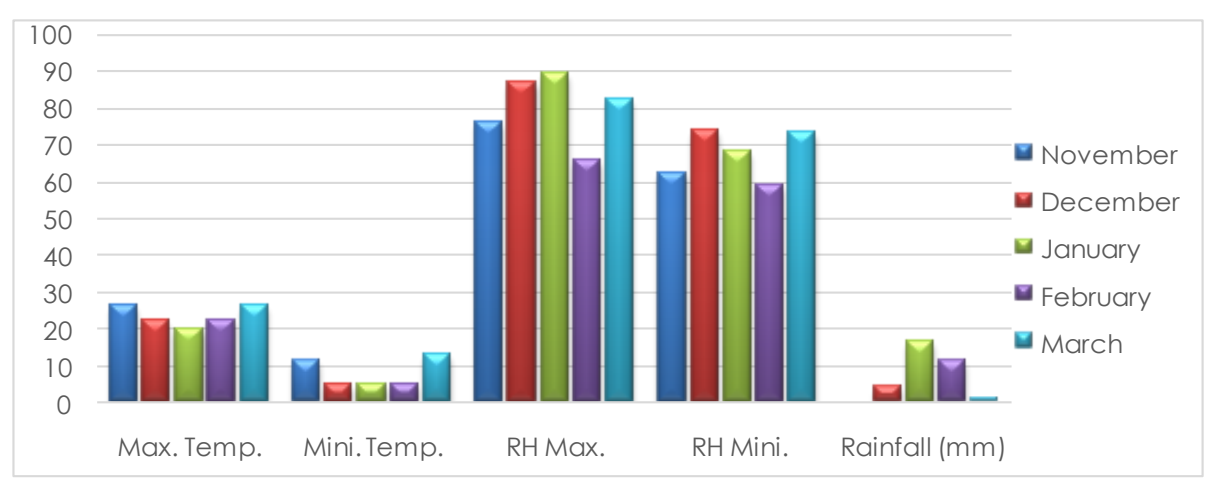


Fig.2 Effect of seed priming with botanical extracts on Plant Height at 60 DAS and 90 DAS

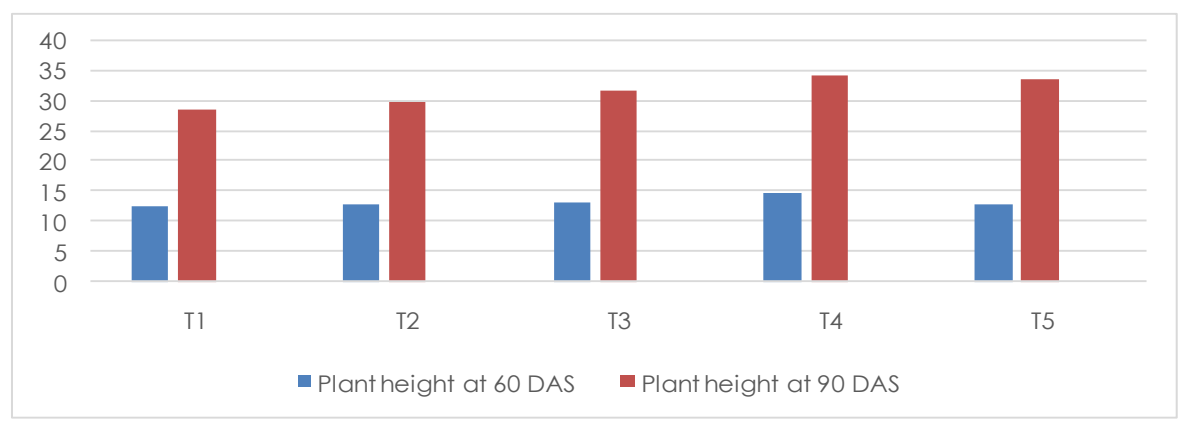

Fig.3 Effect of seed priming with botanicals on fresh weight of plant at 60 DAS

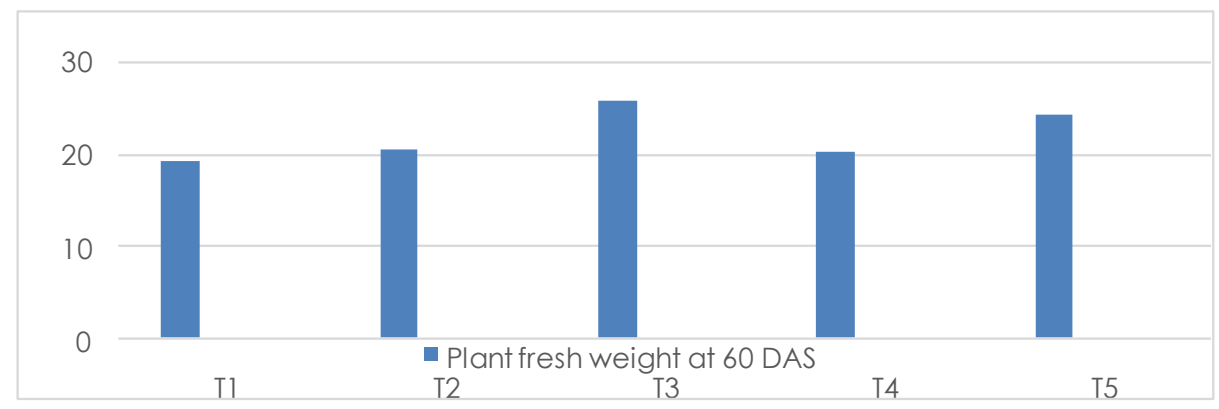

Fig.4 Effect of seed priming with botanicals on total dry matter of plant at 60 DAS

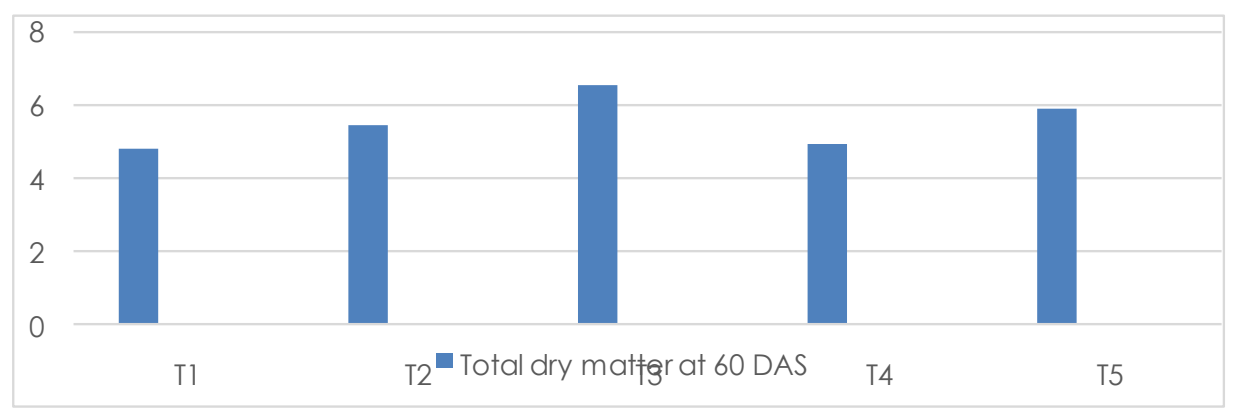

Fig.5 Effect of seed priming with botanicals on Days to $50 \%$ flowering

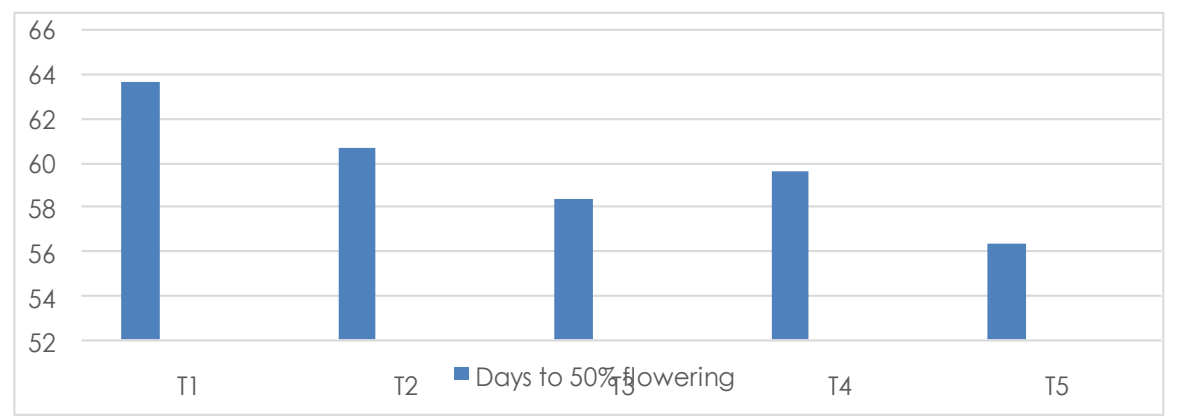


Fig.6 Effect of seed priming with botanicals on Stem dry weight at 50\% flowering

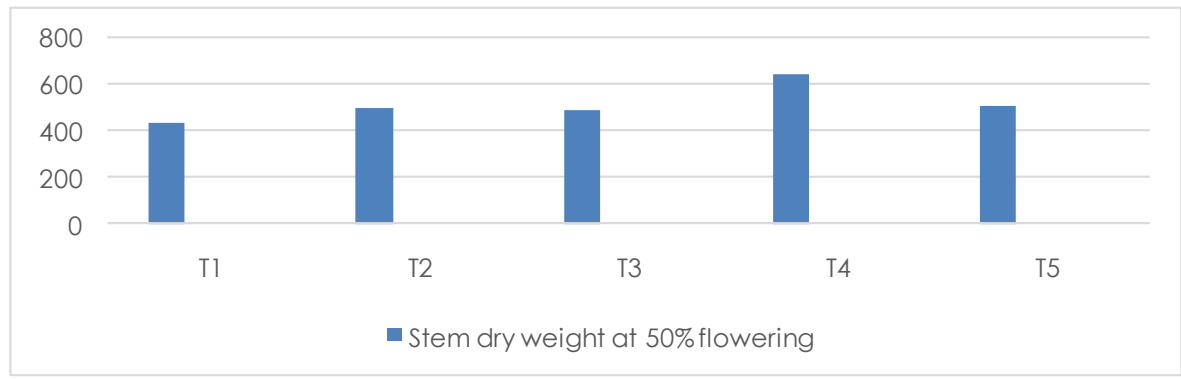

Fig.7 Effect of seed priming with botanicals on Leaf dry weight at 50\% flowering

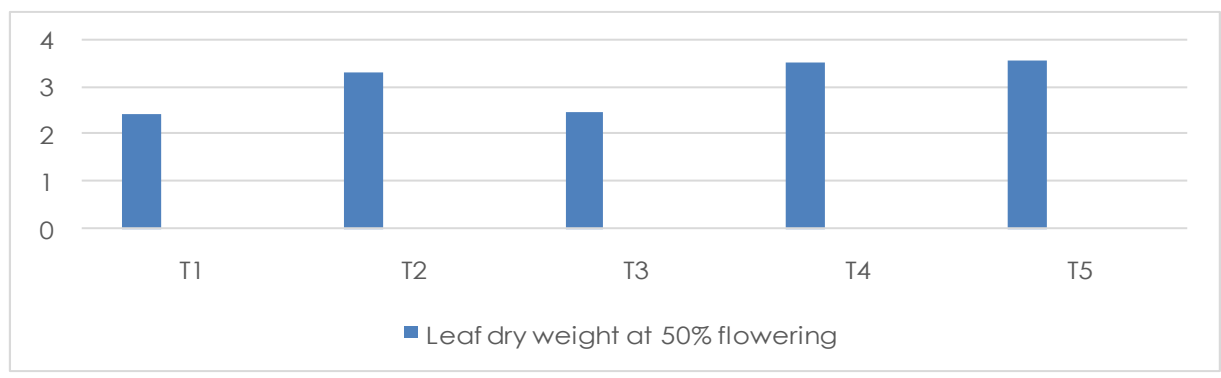

Fig.8 Effect of seed priming with botanicals on Pods per plant

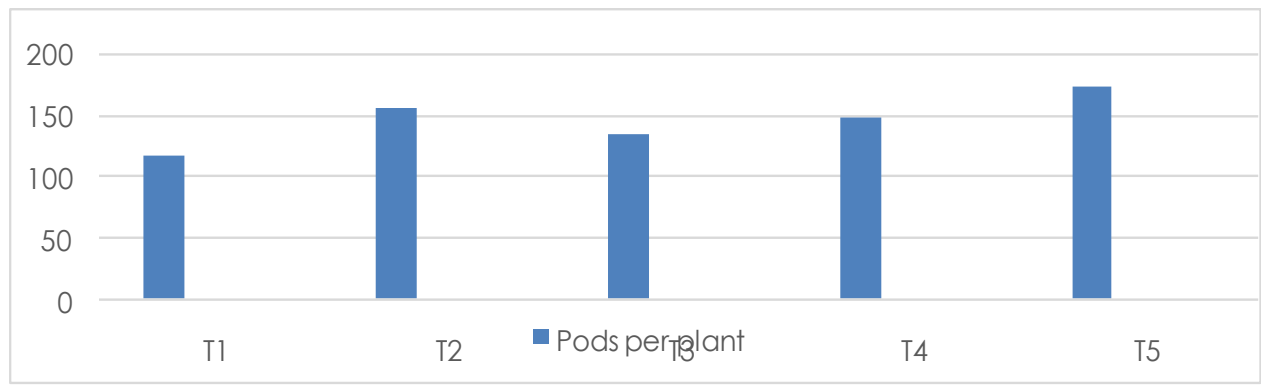

Fig.9 Effect of seed priming with botanicals on Seeds per pod

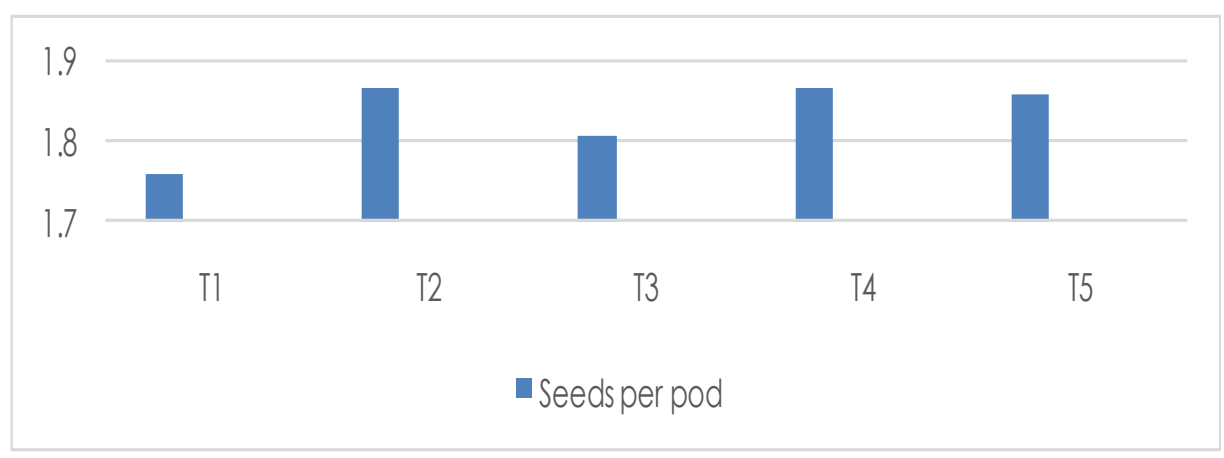


Fig.10 Effect of seed priming with botanicals on yield per plant

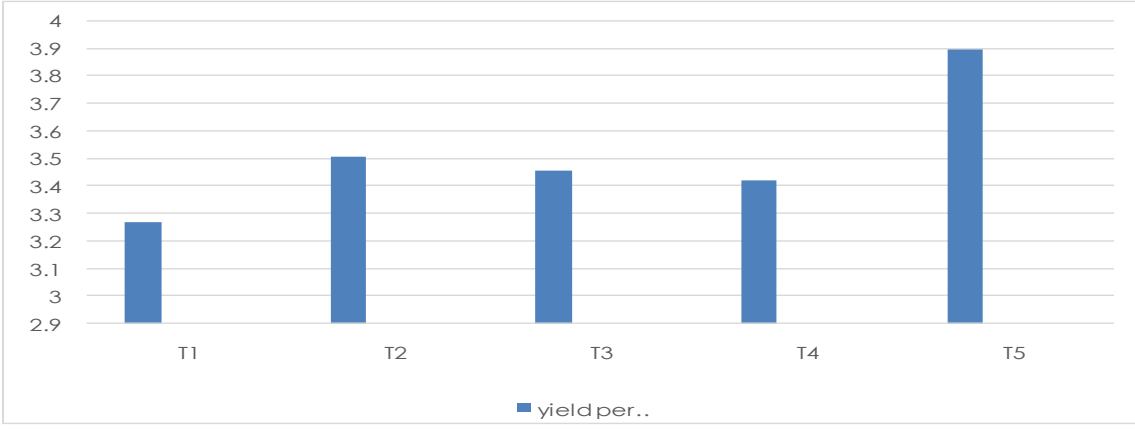

Fig.11 Effect of seed priming with botanicals on yield per plot

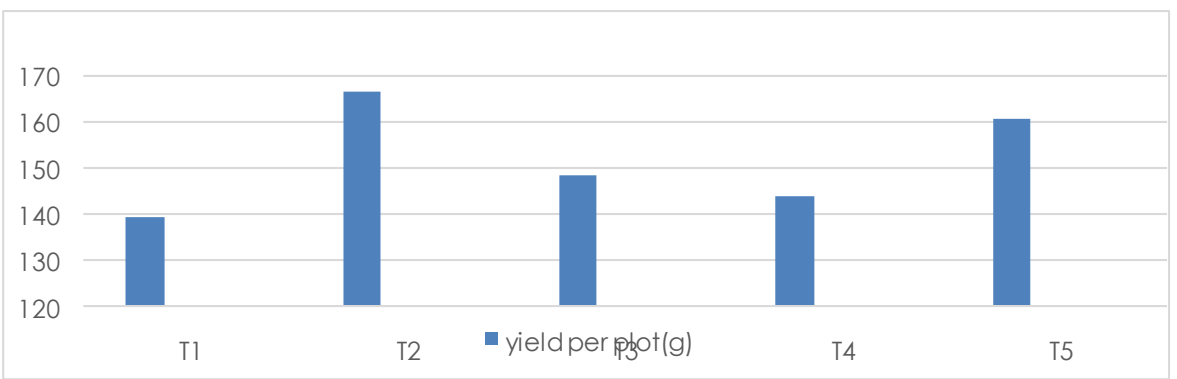

Fig.12 Effect of seed priming with botanicals on yield per hectare

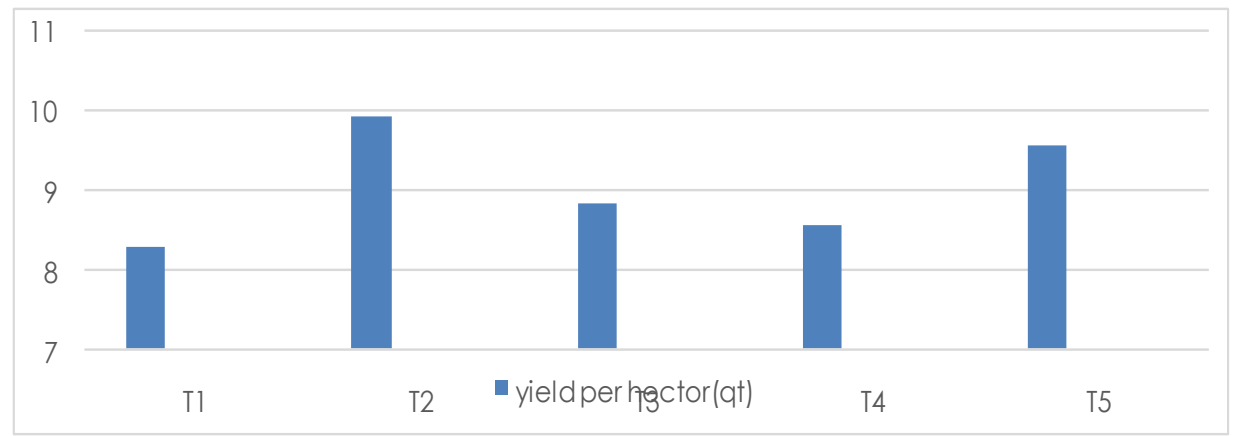

Fig.13 Effect of seed priming with botanicals on 1000 seeds weigh

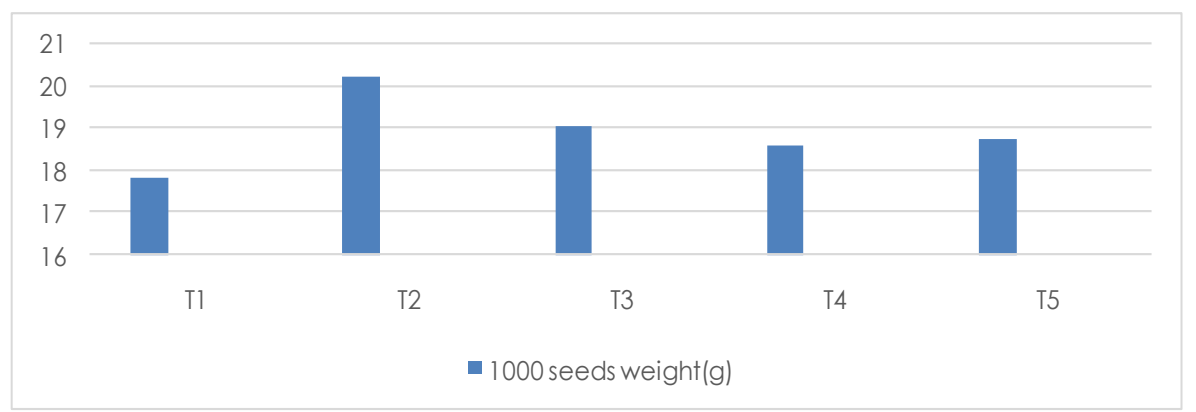




\section{0 seeds weight $(g)$}

The data on 1000 seeds weight, presented in Table 4.6 indicated significant differences between various treatments (Fig.13). Among the treatments, $T_{2}$ recorded significantly higher 1000 seeds weight (20.24 g), followed by $\mathrm{T}_{3}(19.07 \mathrm{~g}), \mathrm{T}_{5}(18.73 \mathrm{~g})$ and $\mathrm{T}_{4}(18.59$ g).Whereas, minimum 1000 seeds weight $(17.83 \mathrm{~g})$ was found in $\mathrm{T}_{1}$.

Organic farming is a production system which avoids or largely excludes the use of synthetically produced fertilizers, pesticides, growth regulators and livestock feed additives. To the maximum extent, possible organic farming system depend on upon crop rotations, crop residues, animal manures, legumes, green manures, off farm organic wastes, mineral bearing rocks and biofertilizers to maintain soil productivity, tilth and to supply plant nutrients and biological means to control insects, weeds and pests.

\section{Growth parameters}

The data with respect to germination, plant height, number of branches per plant, plant fresh weight and dry weight, leaf dry weight, stem dry weight and days taken to $50 \%$ flowering has shown significant differences due to seed priming with various botanicals. Seed priming with neem extracts resulted as maximum germination percentage $(90.80 \%)$ in lentil. The result is in conformity with Ahmed et al., (2014). He observed increased germination percentage in rice seeds, when treated with neem extract (1:1). Khatun et al., (2010) also observed increased germination percentage in lentil seeds treated with neem leaf powder. Hasan et al., (2005) found that extract of onion bulb and leaf extract of neem increased seed germination by decreasing the viral infection. The maximum plant height at 90 DAS was observed in seeds primed with onion extract, whereas number of branches increased due to seed priming with neem leaf extract. Similar results were observed by Janardhan (2014) in urdbean. Shinde (2012) also observed the similar results. Among the botanical extracts, significant differences in flowering was observed.

The use of botanical extracts recorded less days to produce $50 \%$ flowers when compared to control. Janardhan (2014) also noted that treatment with botanical extract including neem leaf extract taken 2-3 days less from control to flowering. The stem dry weight at the day of $50 \%$ flowering was higher due to seed priming with ginger, whereas leaf dry weight was higher in seeds primed with onion extract.

\section{Yield parameters}

The data with respect to pods per plant, seeds per pod, yield per plant and yield per hectare has shown significant differences due to seed priming with various botanicals i.e. neem leaf extract, castor oil, ginger extract and onion extract.

The seed priming with onion bulb extract was resulted as maximum pods per plant, whereas seed priming with neem leaf extract and ginger extract were resulted as maximum seeds per pod. Shinde (2012) and Janardhan (2014) have also found the similar results in seed treatment with neem leaf extract. The increase in yield attributes also increased seed yield in plants.

The maximum seed yield per plant and seed yield per hectare were observed when seed treated with neem leaf extract. It resulted as $19.90 \%$ increase in yield when compared to control. Pradhan et al., (2015) also revealed that neem leaf treated seeds of paddy have outstanding seed yield. Similar results were recorded by Shinde (2012) in mungbean. He 
used the botanicals viz., Lantana camara, Azadirachta indica and cassia tora and found that all spraying treatments increased seed yield of mungbean over control. The data with respect to 1000 seeds weight revealed that seed priming with neem leaf extract have higher test weight when compared to control.

It may be concluded from the present investigation that the use of botanical extracts i.e. neem leaf extract, castor oil, ginger extract and onion extract for seed priming can be done to obtain superior growth and yield in lentil. The seed priming with $50 \%$ extract of garlic inhibits germination due to the presence of Allicin. However, the maximum yield was obtained when seeds were primed with neem leaf extract $(50 \%)$.

\section{References}

Abiamere, C.O., Nweke, F.N., Ogbadu, L.J., Onyia, O.C. and John, C.O, 2014. Evaluation of Moringa oleifera, Zingiber officinale (ginger), Chromolena odorata plants extract as seed borne of cowpea. iosr journal of pharmacy and biological sciences, volume 9, issue 6 ver. iv (nov dec. 2014), pp 66-70.

Adsule R, N. and Kadam, S. S. 1989. Nutritional Chemistry, Processing Technology, and Utilization. Lentil in Handbook of World Food Legumes. D. K. Salunkhe, S. Kadam, eds. CRC Press, Inc, Boca Raton, Florida, Vol II: 131-152.

AhmedMansur, Mehbub Hossain, Kamrul Hassan, Chandra Kanta Dash, 2013. Efficacy of Different Plant Extract on Reducing Seed Borne Infection and Increasing Germination of Collected Rice Seed Sample. Universal Journal of Plant Science 1(3): 66-73.

Ashrafuzzaman H, Hossain I, 1992. Antifungal activity of crude extracts of plants against Rhizoctonia solani and Bipolarissorokiniana. Proc, BAU. Res. Prog. 6:188-192.

BharathN. H., N. K. Hemanth kumar\& Shobha
Jagannath,2014. Allelopathic efficacy of Zingiber officinale rosc aqueous leaf, stem and rhizome extract on early seedling growth of zea mays 1. Global Journal of Biology, Agriculture and Health Sciences. vol.3(3):166-170

Bharathi R, Vivekananthan R, Harish S, Ramanathan A, Samiyappan R, 2004. Rhizobacteria-based bio-formulations for the management of fruit rot infection in chillies. Crop Protection. 23(9):835-43.

Bowers JH, Locke JC. 2000 Effect of botanical extracts on the population density of Fusarium oxysporum in soil and control of Fusarium wilt in the greenhouse. Plant disease. Mar;84(3):300-305

Bowry, S. K., Pandey, N. D. and Tripathi, R. A. 1984. Evaluation of certain oilseed cake powders as grain protectant against Sitophilus oryzae L. Indian journal of entomology. 46(2): pp 196-200.

Deepti P, Swati N, Poonam K, Yogesh KR, Chauhan JS. 2016. Effect of seed priming with some plant leaf extracts on seedling growth characteristics and root rot disease in Tomato. Int J of Agri System, 4(1): 4651.

DialloM.D., R. Duponnoisc, A. Guissea, S. Sallb, J.-L. Chotteb, J. Thiouloused, 2006. Biological effects of native and exotic plant residues on plant growth, microbial biomass and $\mathrm{N}$ availability under controlled conditions. European Journal of Soil Biology 42: 238-246

Foidl N, Makker HPS, Becker K. 2001.The potential of Moringa oleifera for agricultural and industrial uses. In: Fugil, L. J. (eds), The miracle Tree: The multiple attributes of moringa, 45-76.

George, V. and patel, J. R. 1992. Mint mentha spicata promising botanical protectant for green against pulse beetle Callosobruchusa nalis. Indian journal of plant protection. 20: pp 66-69.

GunasekarJ., A. Kamarajand S. Padmavathi, 2017. Effect of presowing seed priming treatment using botanical leaf extract on growth and yield characters in blackgram (vigna mungo [L.] HEPPER) cv. CO 6. 
Vol. 17 No. 2, 2017 pp. 1013-1016.

Hasan, M. M., Chowdhury, S. P., Shahidul Alum, Hossain, B. and Alam, M. S. 2005. Antifungal effects of plant extracts on seed-borne fungi of wheat seed regarding seed germination, seedling health and vigour index. Pakistan Journal of Biological Sciences. 8 (9): pp 1284-1289.

Hossain I, Schlosser E. 1993. Control of Bipolarissorokiniana in wheat with neem extracts [in Bangladesh]. Bangladesh Journal of Microbiology (Bangladesh) 10(1): 39-42.

Ivbijaro, M. F. and Agbaje, M. 1986. Insecticidal activities of Piper guineenseschum and thonn and capsicum spp. on the cowpea bruchid, Callosobruchus maculatus. Insect science and its application. 7(4): pp 521-524.

Janardhan, J.S. 2014. effect of botanicals on seed yield and storability of urdbean [Vigna mungo L. Hepper]. M.Sc. Agri. Thesis submitted to M.P.K.V. Rahuri.

Keshavulu, K. and Krishnasamy, V. 2005. Effect of seed colouring on seed quality and bruchid damage in soybean. Seed Research. 33(2): pp 208-210.

Khan, I. A. and Chaturvedi, O.P. 2007. Germination and seedling growth response of pulsecrops to leaf extracts of tree species. Range Management and Agroforestry. 28(1): 47-50.

Khatun, G. Kabir, M. A. H. Bhuiyan And D. Khanam, 2011. Effect of preserved seeds using different botanicals on seed quality of lentil. Bangladesh J. Agril. Res. 36(3): 381-387.

Khatun, M. A. H. Bhuiyan, G. Kabir and A. K. M. M. Haque. 2010. Effect of different botanicals on the seed quality of lentils during storage. Bull. Inst. Trop. Agr., Kyushu Univ. 33: 19-26, 2010

KumarSanoj, Gabrial M Lal and Prashant Kumar Rai, 2017. Effects of seed treatments with botanical, chemical, on seed yield and quality traits in groundnut (Arachis hypogea L. Journal of Pharmacognosy and Phytochemistry; 6(4): 10-13
Kumar, R., Rai, G. K., Sing, J., Verma, A. and Rai, M., 2008, Stage dependent change in fruit quality characters of tomato (Solanum lycopersicum L.). Third Indian Hort. Course, P-30.

Kumbhar, R.I. 1999. Influence of seed treatment and container on seed quality during storage in chickpea. M.Sc. (Agri.) Thesis. Univ of Agri. Sci. Dharwad.

Ladizinsky, G., 1979. The origin of lentil and its wild genepool. Euphytica, 28(1), pp.179187.

Mishra AK, Dubey NK, 1994. Evaluation of some essential oils for their toxicity against fungi causing deterioration of stored food commodities. Appl. Environ. Microbiol. 60(4):1101-1105.

Muehlbauer F. J., and A Tullu. 1997. Lens culinaris Medik. Avaiable: http://www.hort.purdue.edu/newcrop/crop factsheets/lentil.html [4 February 2014].

Muthuvel, 2002, effect of organics on growth and yield of bhendi var. varsauphar in panchagavya as potentiator of plant cells: effect on crop plants and the physiology that validates the effect, ed, e., vadivel, proc, national, conf, glory of gomatha, dec.1-3, 2007, S. V. veterinary univ, Tirupati, A. P., pp. 143-148.

Narayanan G Sathiya, Singaravelan G, KR, M Prakash. 2016. Effect of pre sowing botanical seed treatment on seed yield and quality in sesame (Sesamum indicum L.) cv. TMV 3. European Journal of Biotechnology and Bioscience. Volume 4; Issue 11; November 2016; Page No. 3840

Ogunyemi Sola, A. FoiukeOdewole 2011. Effect of Neem (Azadirachta indica A. Juss) on Seed Germination of Senna sophera L. Roxb and Crotalaria ochroleuca G. Don. The African Journal of Plant Science and Biotechnology.

PerellóAnalía, Martin Gruhlke, Alan J. Slusarenko. 2013. Effect of garlic extract on seed germination, seedling health, and vigour of pathogen-infested wheat. Journal of plant protection research. Vol. 53, No. 4 (2013) 
Pradhan Biswajit, Kundu Sritama and Kundagrami Sabyasachi, 2015. Role of Seed Treatment with Herbal Plant Products and Management Practices with Growth Nutrients by Decreasing Chlorophyll Reduction Rate for Overcoming Submergence Stress in Rice (Oryza Sativa L.). International Research Journal of Biological Sciences. Vol. 4(5), 38-43.

Rao, M.S., Reddy, P.P., Somasekhar, N. and Nagesh, M., 1997. Management of RootKnot-Nematodes, Meloidogyne Incognita in Tomato Nursery by Integration of Endomycorrhiza, Glomus Fasciculatum with Castor Cake. Pest Management in Horticultural Ecosystems, 3(1).

Rathinavel K, Dharmalingam C. 1999. Seed hardening to augument the productivity of cotton cv. LRA 5116 (Gossypium hirsutum L.). Madras Agri J, 86: 68 -72.

Saha, B.N., W. Islam and A.R. Khan. 2006. Effect of Azadirachtin on the growth and development of the pulse beetle, Callosobruchus chinensis L. Journal. Asiat. Soc. Bangladesh Sci. 32 (1): 69-65.

ShahiduzzamanMd.. 2015. Efficacy of fungicides and botanicals in controlling foot and root rot of lentil. Bangladesh J. Agril. Res. 40(4): 711-715.

Shakeel I, Irfan A, Muhammad A, Ahsan A, Khalid M, Seef P. 2014. Seed priming with aqueous plant extract improved seed germination and seedling growth under chilling stress in Lentil. Adv in app agri sci, 2(11): 58-59.

Shamsa K, Shahnaz D, Marium T. 2015. Impact of seed priming with Carica papaya extract in the control of root infecting fungi and growth of chick pea and mash bean. Int J Bio Res, 3(2): 119-123.

Shinde, A.A. 2012. Effect of botanicals on seed yield and storability of mungbean. M.Sc. Agri. Thesis submitted to M.P.K.V. Rahuri.

Singh, A.K., Singh, S.S., Prakash, V., Kumar, S. and Dwivedi, S.K., 2015. Pulses production in india: Present status, sent status, bottleneck and way forward. Journal of AgriSearch,2(2), pp.75-83.

Sivritepe N, Sivritepe HO, Eris A. 2003. The effects of $\mathrm{NaCL}$ priming on salt tolerance in melon seedling grown under saline conditions. Scientia Horti, 97: 229-237.

Suratuzzaman M, Hossain I, Fakir GA. 1994. Control of seed borne fungi of two rice varieties with some plant extracts. Progressive Agriculture.;5(1):11-15.

Varier A, Vari AK, Dadlani M. 2010. The subcellular basis of seed priming. Current Science. Aug 25;99(4):450-6.

Vasileva V, Ilieva A. 2007. Effect of pre sowing treatment of seeds with insecticides on nodulating ability, nitrate reductase activity and plastid pigments content of Lucerne (Medicago sativa L.). Agro Res, 5(1): 87-92.

Vijayalakshmi, K. and Goswami, B.K. 1986.Effect of seed treatments with neem cake and neem oil onthe germination of (mungbean) Andits vulnerability to rootknot nematode.International nematology network newsletter. 3: 8-9.

Yadav, S., P. Stevenson and McNeil, D. L. 2007. Uses and Consumption of Lentil. S. S. Yadav, D. L. McNeil and P. C. Stevenson, Springer Netherlands: 33-46.

\section{How to cite this article:}

Deepak Chand Bhateshwar, Deepti Prabha, Deepak Jangid and Mohammad Salman. 2020. Effect of Seed Priming with Botanicals on Plant Growth and Seed Yield of Lentil (Lens culinaris M.). Int.J.Curr.Microbiol.App.Sci. 9(07): 3484-3499.

doi: https://doi.org/10.20546/ijcmas.2020.907.407 